\title{
STUDENT PERCEPTION ABOUT HIV / AIDS WITH THE STIGMATIZATION OF PLWHA
}

\author{
Pius A.L. Berek ${ }^{2)}$ \\ Maria Dominggas Taus ${ }^{1)}$ \\ Maria Huring ${ }^{3)}$ \\ Christina Anugrahini ${ }^{4)}$
}

\begin{abstract}
1, 2, 3,4 : Nursing Program at University of Timor, Jl. Wehor Kabuna Haliwen, Atambua, East Nusa Tenggara, Indonesia. E-mail: francis_domin2012@yahoo.com Phone number:

$$
+6281280426042
$$
\end{abstract}

\begin{abstract}
Cases of HIV / AIDS until now is increasing and has not found a cure. Listed as one of the most deadly diseases. The cause of this disease because of sex is not healthy, drug users using needles infected with HIV / AIDS, blood transfusions, babies born to positive mothers infected with HIV / AIDS. Their underlying cause of the disease is that there are some people who have a negative perception so that they will give a stigma for people living with HIV. It also extended to the campus community. This study Aimed to identify the relationship between the student persespsi with stigmatization of PLWHA. The approach used is quantitative approach with cross sectional study design. Reviews These samples included 236 students. Data analysis using chi square. Based on test results Obtained statistical value of $p$ $=0.000$, it can be concluded that there is a correlation between students' perceptions about HIV / AIDS with the stigmatization of PLWHA. From the results Obtained by analysis of the value $O R=5.844$, it means that students who have positive perceptions about HIV / AIDS have the opportunity to give 5,844 times stigmatization for people living with HIV than students who have a negative perception. Suggestion: it is Necessary to access the latest information on HIV / AIDS in order to Broaden so as to change the wrong perceptions about HIV / AIDS so that no stigma for people living with HIV.
\end{abstract}

\section{Keywords:}

Student perception, HIV / AIDS, stigmatization of PLWHA 


\section{Background}

Along with the development of science and technology are increasingly modern, people's living conditions more difficult and complex. One problem that until now the health impact, social, economic and political, namely HIV / AIDS (Human Immunodeficiency Virus Acquiered immunodeficiency syndrome). (Fernandes et al., 2008).

HIV is a virus that can spread from one person to another in a specific way and can cause weakens a person's immune system so that it can cause health problems continued with ease. AIDS is a collection of symptoms of diseases caused by the immune system so that (Padila 2012).

The problem of HIV / AIDS is not only a national problem, but has become a global problem. It is worthy of serious attention by each individual. In everyday life, social interaction within the community is very complex. We can find in people with HIV / AIDS where the different treatment, such as shunned, ostracized, discrimination (Hermawati, 2011). All of this is related to one's perception of a problem, including the problem of HIV AIDS. According Walgito (in Hermawati 2011) perception is a process that takes precedence by sensing. Sensing is a process of receipt of stimulus by the individual through the receiver ie sensory organs.

Individual circumstances may affect the results of one's perception. There are two sources that affect in terms of bodily or physical and psychological terms. If the physiological system is compromised, it will affect the person's perception. While the psychological aspect is about the experience, feeling, thinking, motivation will affects against one's perception. (Setiawati, 2008).

This phenomenon that stimulates and motivates writers to understand and examine more deeply the relationship student perceptions about HIV / AIDS with stigma for people living with HIV and lift the title "Relationship between Student Perception of HIV / AIDS with stigmatization for people living with HIV/AIDS (PLWH) in Atambua East Nusa Tenggara". Based on the background, the formulation of the problem in the research is "How the Corelation Between Student Perception of HIV / AIDS with stigmatization for people living HIV/AIDS in Atambua East Nusa Tenggara".

Fauk et al., (2018) Findings indicated three main barriers of accessing HIV testing services by clients. These included: (1) personal barriers (lack of knowledge of HIV/AIDS and HIV testing availability, and unwillingness to undergo HIV testing due to low self-perceived risk of HIV and fear of the test result); (2) health care service provision barriers (lack of trust in health professionals and limited availability of medication including antiretroviral (ARV)); and (3) social barriers (stigma and discrimination, and the lack of social supports).

Berek, et al., (2018) in their research note there is no relationship between age and level of knowledge of adolescents with HIV / AIDS ( $\mathrm{p}=0.591$ at 0.05 alpha) but there is a significant relationship between sex with adolescent knowledge level about HIV / AIDS with $p=0.010$ at alpha 0.05.

Data analysis was performed with univariate and bivariate analyzes. Univariate analysis was conducted to determine the characteristics of respondents included age, gender, student perceptions about HIV / AIDS and the stigmatization of PLWHA.

Bivariate analysis to find the relationship between the two variables, using techniques chi square test using SPSS program (statistical software program Social Science Version 22 Windows XP). 


\section{RESULTS}

\section{Univariate Analysis}

Characteristics of Respondents by Age Distribution of the average age of respondents in this study can be seen in table 1

\section{Table 1}

Distribution of Respondents by Age in Atambua $(N=236)$

\begin{tabular}{ccccc}
\hline Variabel & Mean & SD & Min-Maks & $95 \%$ CI \\
\hline Age & 20.98 & 2.854 & $17-34$ & $20.62-21.35$ \\
\hline
\end{tabular}

The analysis show that the average age of respondents was 20.98 years $(95 \%$ CI 20.62- 21:35), with a standard deviation of 2,854 . The youngest age is 17 years old and the oldest was 34 years old. From the estimation interval can be concluded that $95 \%$ believed that the average age of respondents in this study is $20.62-21.35$ years.

\section{Characteristics of Respondents by Gender}

The average distribution by gender in this study can be seen in the table 2

Table 2

Frequency Distribution of Respondents by Gender in Atambua $(N=236)$

\begin{tabular}{lccc}
\hline Variabel & Kategorik & F & Presentation (\%) \\
\cline { 2 - 4 } & Male & 55 & 23.3 \\
\cline { 2 - 4 } & Female & 181 & 76.7 \\
\cline { 2 - 4 } & Total & 236 & 100
\end{tabular}

The analysis show that the proportion of respondents who are women is as much as $76.7 \%$ (181 people) and men as much as $23.3 \%$ (55 people).

\section{Student Perception About HIV / AIDS}

Student perception about HIV / AIDS in this study can be seen in the table 3

Table 3

Student Perception About HIV / AIDS in Atambua $(N=236)$

\begin{tabular}{cccc}
\hline Variabel & Kategorik & $\mathrm{f}$ & Presentation (\%) \\
\cline { 2 - 4 } Perception & Positive & 129 & 54.7 \\
\cline { 2 - 4 } & Negative & 107 & 45.3 \\
\cline { 2 - 4 } & Total & 236 & 100 \\
\hline
\end{tabular}

Based on the table can be seen that $54.7 \%$ (129 people) have positive perception about HIV AIDS and respondents who have a negative perception about HIV AIDS is $45.3 \%$ (107 people).

\section{Stigmatization to People Living With HIV Patients}

Stigmatization of PLWHA in this study can be seen in the table 4

Table 4

Stigmatization of PLWHA

in Atambua $(N=236)$

\begin{tabular}{cccc}
\hline $\begin{array}{c}\text { Variabel } \\
\text { Stigmatization }\end{array}$ & Kategorik & f & $\begin{array}{c}\text { Presentation } \\
(\%)\end{array}$ \\
\cline { 2 - 4 } & Yes & 115 & 48.7 \\
\cline { 2 - 4 } & No & 121 & 51.3 \\
\cline { 2 - 4 } & Total & 236 & 100
\end{tabular}

Based on the table can be seen that there is $48.7 \%$ (115 people) gives stigmatization to people living with HIV, and 51.3\% (121 people) do not give stigmatization to PLWHA.

\section{Bivariat Analysis}

Bivariate analysis aims to determine the relationship between students' perception about HIV AIDS with the stigmatization of PLWHA. In this analysis using chi square test for both data has been categorized. The analysis of these two variables can be seen in table 5 below. 


\section{Table 5}

Relationship Between Student Perception About HIV / AIDS With Stigmatization of PLWHA $(N=236)$

\begin{tabular}{|c|c|c|c|c|c|c|c|c|}
\hline \multirow[t]{2}{*}{ Variabel } & \multicolumn{4}{|c|}{ Stigmatization to PLWH } & \multirow[t]{2}{*}{ Total } & \multirow[t]{2}{*}{$\%$} & \multirow{2}{*}{$\begin{array}{c}\text { OR } \\
(95 \% \\
\text { CI) } \\
\end{array}$} & \multirow{2}{*}{$\begin{array}{c}\mathrm{P} \\
\text { Value }\end{array}$} \\
\hline & Yes & $\%$ & No & $\%$ & & & & \\
\hline \multicolumn{9}{|l|}{ Perseption: } \\
\hline Negative & 28 & 26.2 & 79 & 73.8 & 107 & 45.3 & \multirow{3}{*}{$\begin{array}{c}5.844 \\
(3.315- \\
10.303)\end{array}$} & \multirow[t]{3}{*}{0.000} \\
\hline Positive & 87 & 67.4 & 42 & 32.6 & 129 & 54.7 & & \\
\hline & 115 & 48.7 & 121 & 51.3 & 236 & 100 & & \\
\hline
\end{tabular}

The analysis of the relationship between student perception about HIV / AIDS with the stigmatization of PLWHA known that there are 79 people $(73.8 \%)$ of respondent who have a negative perception did not provide the stigmatization to people living with HIV, and there are 87 people $(67.4 \%)$ of respondents who have a positive perception gives stigmatization to PLWHA. Statistical test results obtained $\mathrm{p}$ value is $0.000(\alpha=0.05)$, it can be concluded that there is a significant relationship between students' perceptions about HIV / AIDS with the stigmatization of PLWHA. Further analysis of the results obtained by the OR value is 5,844 , it means that students who have positive perceptions about HIV / AIDS have the opportunity to give 5,844 times stigmatization for people living with HIV than students who have a negative perception.

\section{DISCUSSION}

Perception is a process that takes precedence by pengideraan. Sensing is a process of receipt of stimulus by the individual through the receiver ie sensory organs. A state of individuals can influence the outcome of perception. There are two sources that influence a person's perception is related to the terms of a bodily / physical and psychological aspects. If the physiological system is compromised, it will affect a person's perception. While the psychological aspect is about experiences, feelings, ability to think, reference framework, motivation will affect the person who will do the perception (Hermawati, 2011). Based on the results of a study of 236 respondents note that respondents' perceptions about HIV AIDS is $54.7 \%$ (129 people) have positive perception as about HIV/AIDS and respondents who have a negative perception about HIV AIDS is $45.3 \%$ (107 people).

Stigma is a defect or blemish on the character of someone. Major societal stigma to people living with HIV / AIDS is due to HIV / AIDS infection connotes any form of "negative" (Hermawati, 2011). An opinion states that $80 \%$ of the disease is transmitted through sexual intercourse, the rest are intravenous drug addicts, sex workers (prostitutes), wives who contracted the disease from her husband and mother who gave birth to HIV positive children. In short, people with HIV / AIDS is the interaction of people who are free (free sex), drug addicts, people who violate the norms of religious and social. Based on the results of a study of 236 respondents showed that there were $48.7 \%$ (115 people) gives stigmatization of people living with HIV, and $51.3 \%$ (121 people) do not give stigmatization to PLWHA.

Results of the analysis of the relationship between students' perceptions about HIV / AIDS with the stigmatization of PLWHA known that there are as many as 79 people $(73.8 \%)$ of respondents who have a negative perception did not provide to the stigmatization of people living with HIV, and there are 87 people $(67.4 \%)$ of respondents who have a positive perception gives stigmatization to PLWHA. Further analysis of the results obtained by the value $\mathrm{OR}=5,844$, it means that students who have positive perceptions about HIV/AIDS have 5,844 times opportunity to give stigmatization to people living with HIV than students who have a negative perception.

According to the researchers, this is very unfortunate because the student who have a positive perception is precisely to know and want to give stigmatisai for PLWHA. Poor understanding of HIV / AIDS in the community need to be 
minimized. HIV/AIDS is not a way to fight against HIV/AIDS but rather a way to fight against the spread of HIV. When people, especially students give a negative stigma, then the burden will be even greater suffering. The people living with HIV should get serious attention and avoid from possibility to despair. Because desperate that PLWHA could perform actions such as ending the life by suicide or other things that are not expected. Indeed discrimination against persons with HIV / AIDS not only violates human rights, but it did not help efforts to prevent the spread of the HIV virus. Stigma and discrimination are both incarnated as a barrier handling the spread of HIV / AIDS. Many people who think HIV / AIDS should be shunned and unwanted presence in envinronment.

The results of this study are also supported by the research of (Berek \& Bubu, 2019) which in his research found that education and work found a significant relationship, namely those with low education had a chance of 2.23 times more likely to stigmatize PLWHA compared to people who had advanced education to tertiary education ( $\mathrm{p}$ value $=$ $0.028 ; \mathrm{OR}=2.23 ; 95 \% \mathrm{CI}=1.04-4.45)$; and people who don't work have a possibility of 1.42 times to stigmatizing PLWHA compared to people who have working $(\mathrm{p}$ value $=0.007 ; \mathrm{OR}=1.42 ; 95 \%$ $\mathrm{CI}=0.22-0.78)$.

Negative stigmatization for PLWHA will also affect adherence to taking ARV drugs, as a study found by Tae et al., (2019) which found that there were $12.5 \%$ of respondents who were not compliant with the consumption of ARV drugs. This will worsen the patient's condition and even cause death.

\section{Conclusion}

Based on the results of this study can be summarized as follows:
1. Respondents' perceptions about HIV/AIDS isvary. It is $54.7 \%$ have positive perception and $45.3 \%$ of respondents have a negative perception about HIV/AIDS.

2. There are $48.7 \%$ give stigmatization of people living with HIV, and $51.3 \%$ did not give stigmatization to PLWHA.

3. There are $73.8 \%$ of respondents who have a negative perception did not provide the stigmatization of people living with HIV, and there are $67.4 \%$ of respondents who have positive perception give a bad stigma to PLHA. Statistical test results obtained by $p$ value is $0.000(\alpha=0.05)$ it can be concluded that there is a correlation between students' perceptions about HIV / AIDS with the stigmatization of PLWHA. From the results obtained by analysis of the OR value OR is 5,844, it means that students who have positive perceptions about HIV / AIDS have the opportunity 5,844 times to give the stigmatization to people living with HIV than students who have a negative perception. For further research, it is recommended to increase the number of samples is more varied with emphasis on the category of adolescence.

\section{REFERENCES}

Berek, P. A. L., Be, M. F., Rua, Y. M., \& Anugrahini, C. (2018). Hubungan Jenis Kelamin dan Umur Dengan Tingkat Pengetahuan Remaja Tentang HIV/AIDS di SMAN 3 Atambua, Nusa Tenggara Timur. Jurnal Sahabat Keperawatan, 1, 1-13. Retrieved from https://jurnal.unimor.ac.id/JSK/article /view/85

Berek, P. A. L., \& Bubu, W. (2019). Hubungan Antara Umur, Jenis Kelamin, Pendidikan dan Pekerjaan dengan STigmatisasi Terhadap Orang Dengan HIV/AIDS di RSUD Mgr. Gabriel Manek, SVD Atambua. Jurnal Sahabat Keperawatan, 2(1), 
36-44. Retrieved from

https://jurnal.unimor.ac.id//JSK

Fauk, N. K., Sukmawati, A. S., Berek, P.

A. L., Ernawati, Kristanti, E., Wardojo, S. S. I., ... Mwanri, L. (2018). Barriers to HIV testing among male clients of female sex workers in Indonesia. International Journal for Equity in Health, 17(1), 1-10. https://doi.org/10.1186/s12939018-0782-4

Tae, F., Riwoerohi, E. D. F., \& Berek, P. A. L. (2019). Gambaran Kepatuhan Minum Obat Antiretroviral Pada Orang Dengan HIV/AIDS di Puskesmas Wedomu Kabupaten Belu Nusa Tenggara Timur. Jurnal Sahabat Keperawatan, 2(1), 61-69. Retrieved from https://jurnal.unimor.ac.id/JSK

Fernandes et al., 2008. HIV/AIDS, PMS and Our Communities. Kupang: Gita Kasih.

Hermawati. 2011. Relationship Between Perceptions of PLHIV to stigmatization of HIV / AIDS Community with Social Interactions on people living with HIV. Access from Http//repository.uinjkt.ac. id/PianHermawati FPS, September $26^{\text {th }}$, 2014.

Ndoen, F. (2016). AIDS Bunuh 241 Warga Belu. Journal, diunduh dari http://kupang.tribunnews.com/2016/0 4/29/aids-bunuh-241-warga-belu. Diakses tanggal 18 Juli 2016

Mandal et al., 2006. Infectious Diseases, sixth edition. Jakarta : Erlangga.

Padila. 2012. Textbook of Medical Surgical Nursing. Yogyakarta : Nuha Medika

Setiawati. 2008. Empowerment of Women in Preventing Spread of HIV / AIDS. Jakarta : EGC.
Suryono et al., 2001. Internal of Medicine, Volume II, Third Edition. Jakarta : FKUI 